\title{
The relationship between serum anti-Müllerian hormone concentrations and fertility, and genome-wide associations for anti-Müllerian hormone in Holstein cows
}

\author{
M. Gobikrushanth, ${ }^{*} \dagger$ D. C. Purfield,† M. G. Colazo, $\ddagger$ S. T. Butler, $†$ Z. Wang, ${ }^{*}$ and D. J. Ambrose ${ }^{*} \ddagger^{1}$ \\ *Department of Agricultural, Food and Nutritional Science, University of Alberta, Edmonton, AB, Canada T6G 2P5 \\ †Teagasc, Animal \& Grassland Research and Innovation Centre, Moorepark, Fermoy, Co. Cork, Ireland, P61 C996 \\ łLivestock Research and Extension Branch, Alberta Agriculture and Forestry, Edmonton, AB, Canada T6H 5T6
}

\begin{abstract}
The objectives of this study were to (1) evaluate factors associated with variation in circulating anti-Müllerian hormone $(\mathrm{AMH})$ concentrations, (2) establish an optimum AMH threshold predictive of pregnancy to first artificial insemination (P/AI), (3) examine the relationship between $\mathrm{AMH}$ and fertility $(\mathrm{P} / \mathrm{AI}$, pregnancy loss between 30 and $60 \mathrm{~d}$ after artificial insemination, and pregnancy risk up to $250 \mathrm{~d}$ postpartum), and (4) identify quantitative trait loci associated with phenotypic variation of AMH concentrations in dairy cows. Serum AMH concentrations $(\mathrm{pg} / \mathrm{mL})$ were determined at $7 \pm 2.4 \mathrm{~d}$ postpartum in 647 lactating Holstein cows (213 primiparous, 434 multiparous) from 1 research and 6 commercial dairy herds in Alberta, Canada. Of these, 589 cows were genotyped on the 26K Bovine BeadChip (Neogen Inc., Lincoln, NE) and subsequently imputed to the Illumina Bovine High Density BeadChip (Illumina, San Diego, CA) for genome-wide association analysis for variation in serum AMH concentrations. Factors associated with variation in serum AMH concentrations and the relationship between categories of $\mathrm{AMH}$ and aforementioned fertility outcomes were evaluated only in a subset of 460 cows that had a complete data set available. The overall mean ( \pm standard error of the mean), median, minimum, and maximum AMH concentrations were $191.1 \pm 6.3,151.7,13.9$, and $1,879.0 \mathrm{pg} / \mathrm{mL}$, respectively. The AMH concentrations were not associated with herd, precalving body condition score, postpartum week, and season of sampling; the lactation number, however, had a quadratic relationship with serum AMH concentrations (116.2, 204.9 204.5 , and $157.9 \mathrm{pg} / \mathrm{mL}$ for first, second, third, and $\geq$ fourth lactation, respectively). The optimum AMH threshold predictive of P/AI could not be established
\end{abstract}

Received October 4, 2017

Accepted March 21, 2018.

${ }^{1}$ Corresponding author: divakar.ambrose@gov.ab.ca because the receiver operating characteristic curve analysis model was nonsignificant. Categories of $\mathrm{AMH}$ [low $(<83.0 \mathrm{pg} / \mathrm{mL} ; \mathrm{n}=92)$, intermediate $(\geq 83.0$ to $\leq 285.0 \mathrm{pg} / \mathrm{mL} ; \mathrm{n}=276)$, and high $(>285.0 \mathrm{pg} / \mathrm{mL}$; $\mathrm{n}=92$ ) based on lowest $20 \%$, intermediate $60 \%$, and highest 20\% serum AMH) had no associations with P/ $\mathrm{AI}(34,43$, and $40 \%)$, pregnancy loss between 30 and 60 $\mathrm{d}$ after artificial insemination $(20,12$, and $8 \%$ ), or pregnancy risk up to $250 \mathrm{~d}$ postpartum. One candidate gene associated with AMH production $[A M H$ gene on Bos taurus autosome (BTA) 7] and 4 candidate genes related to embryo development ( $S C A I$ and $P P P 6 C$ genes on BTA11 and FGF18 and EEF2K genes on BTA20 and BTA25, respectively) were in linkage disequilibrium with single nucleotide polymorphisms associated with phenotypic variation in serum AMH in dairy cows. Key words: fertility trait, genomic heritability, pregnancy loss, superovulation

\section{INTRODUCTION}

A trait that has high variability, repeatability, heritability, and associations with fertility would be an ideal candidate for genetic selection to augment reproductive performance in dairy cows. The use of circulating antiMüllerian hormone (AMH) concentrations as a potential fertility trait in cattle has been of recent interest to many researchers (Ribeiro et al., 2014; Baruselli et al., 2015; Jimenez-Krassel et al., 2015; Gobikrushanth et al., 2017). Anti-Müllerian hormone, a dimeric glycoprotein produced by granulosa cells of growing preantral and antral follicles (La Marca and Volpe. 2006), is a marker of ovarian follicular reserve in cattle (Rico et al., 2009; Monniaux et al., 2012). A positive correlation between circulating $\mathrm{AMH}$ and antral follicle counts (AFC) in cattle has also been reported (Ireland et al., 2008; Rico et al., 2009; Gobikrushanth et al., 2017).

In cattle, AMH concentrations were highly variable among animals but were quite repeatable within an animal (Rico et al., 2009; Monniaux et al., 2012; Ribeiro 
et al., 2014; Gobikrushanth et al., 2017). Maternal nutritional status, species, breed, and lactation number were all identified as potential factors associated with phenotypic variation in AMH concentrations in cattle (Mossa et al., 2013; Batista et al., 2014; Ribeiro et al., 2014). Interestingly, however, the associations between circulating AMH concentrations and reproductive outcomes remain unclear (Ribeiro et al., 2014; Baruselli et al., 2015; Jimenez-Krassel et al., 2015). Hence, additional studies are warranted to further elucidate the factors that affect circulating AMH concentrations and the relationship between circulating AMH and phenotypic fertility performance.

An optimum circulating AMH threshold predictive of pregnancy outcomes to first AI (P/AI), heritability of AMH, and genome-wide association studies (GWAS) identifying SNP associated with phenotypic variation in AMH concentrations are novel aspects yet to be explored in dairy cows. If a positive association exists between $\mathrm{AMH}$ and reproductive outcomes and an optimum AMH threshold could be established, it will assist dairy producers to make economically beneficial decisions by selectively breeding cows with high $\mathrm{AMH}$ to improve reproductive efficiency of dairy herds. In addition, identification of genetic makers (SNP) associated with variation in circulating $\mathrm{AMH}$ concentrations would potentially help to identify, and preselect at birth, future elite genetic merit donors with greater embryo production potential for use in multiple ovulation embryo transfer programs in dairy cattle.

Therefore, the primary objectives of the current study were to (1) evaluate the factors associated with variation in circulating AMH concentrations, (2) establish an optimum AMH threshold that has predictive value for $\mathrm{P} / \mathrm{AI}$, (3) examine the relationship among categories of $\mathrm{AMH}$ and fertility $[\mathrm{P} / \mathrm{AI}$, pregnancy loss between 30 and $60 \mathrm{~d}$ post-AI (PLOSS), and pregnancy risk up to 250 d postpartum], and (4) identify QTL associated with phenotypic variation in AMH concentrations in dairy cows.

\section{MATERIALS AND METHODS}

\section{Animals and Management}

This study was conducted in 1 research herd (Dairy Research and Technology Centre, University of Alberta) and 6 commercial dairy herds located in Alberta between November 2014 and 2015. Animals were housed and cared for in accordance with the requirements of Canadian Council on Animal Care (2009). Cows were fed once daily a TMR (primary ingredients were barley or corn silage, alfalfa silage, alfalfa hay, and concen- trates) and had ad libitum access to potable water. Cows from 4 herds were subjected to GnRH-based synchronization protocols and inseminated without estrus detection for first and subsequent AI (timed AI), whereas cows from 3 other herds were inseminated at detected estrus (IDE).

\section{Blood Sampling and Determination of Serum Concentrations of $A M H$}

Blood samples were collected at (mean \pm SD) $7 \pm$ $2.4 \mathrm{~d}$ postpartum from 647 lactating Holstein cows (213 primiparous, 434 multiparous) from a coccygeal blood vessel using evacuated Vacutainer (Becton Dickinson and Company, Franklin Lakes, NJ) into clot-activator tubes (serum tubes) for AMH determination and anticoagulant $\mathrm{K}_{2}$ EDTA coated tubes (EDTA tubes) for genotyping. After collection, serum tubes were left undisturbed for about $2 \mathrm{~h}$ to allow clot formation and were then centrifuged at $1,500 \times g$ for $20 \mathrm{~min}$ at $4^{\circ} \mathrm{C}$, serum harvested, and frozen at $-20^{\circ} \mathrm{C}$ until assayed for $\mathrm{AMH}$. The EDTA tubes were frozen at $-20^{\circ} \mathrm{C}$ until processed for genotyping. Serum concentrations (pg/ $\mathrm{mL}$ ) of AMH were analyzed at Ansh Labs (Webster, TX) using the Ansh Labs Bovine AMH ELISA. The assay has an analytical measurable range of 13.5 to $2,240 \mathrm{pg} / \mathrm{mL}$. The AMH assay limit of detection was $11 \mathrm{pg} / \mathrm{mL}$, and the intra- and interassay coefficients of variation were $<5 \%$.

\section{Determination of BCS, Reproductive Measurements, and Milk Yield for the Current Lactation}

Body condition scores were determined between 1 and 2 wk before the estimated calving date (hereafter referred to as precalving BCS) and again between 4 and 6 wk after calving (hereafter referred to as postcalving $\mathrm{BCS}$ ) on a 1 to 5 scale system measured in increments of 0.25 units $(1=$ thin, $5=$ fat $)$ as previously described (Edmonson et al., 1989). The reproductive data and 305-d mature-equivalent (MEQ) milk yield were retrieved using DairyComp 305 herd management software (CanWest DHI, Guelph, ON, Canada).

\section{Genotyping, Quality Control, and Imputation}

The DNA extraction was performed on blood samples drawn from a subset of 589 lactating Holstein cows using the Qiagen BioSprint 96 DNA (3840) Kit blood and tissue protocol (Qiagen, Toronto, ON, Canada). The DNA samples were normalized and genotyped according to the Illumina Infinium Ultra protocol (Illumina, San Diego, CA) and markers were scored on 
the Bovine Geneseek Genomic Profiler 26K BeadChip (Neogen Inc., Lincoln, NE) at Delta Genomics (Edmonton, AB, Canada). The beadchips were scanned using the Illumina HiScan (Illumina), and the raw data were processed and exported using Genome Studio 2.0 software according to the Genome Studio Framework User Guide (Illumina) based on a selection criterion of at least $95 \%$ animal call rate.

Genotype quality control was performed using PLINK v1.09 (Purcell et al., 2007). All SNP with an unknown $\mathrm{Y}$ chromosomal or mitochondrial position were excluded. In addition, SNP with a call rate $<90 \%$, minor allele frequency $<0.01$, and significant deviation from Hardy-Weinberg equilibrium $\left(P \leq 10^{-6}\right)$ were removed. All animals had a genotype call rate $>90 \%$ and 19,896 SNP remaining after edits. To increase the density of the SNP panel for GWAS, imputation to the Illumina Bovine high-density (HD) beadchip was undertaken using FImpute2 (Sargolzaei et al., 2014). Imputation was completed using a 2-step approach whereby the 589 animals were first imputed to the Illumina BovineSNP50 chip using a reference population of 3,532 Irish Holstein-Friesian BovineSNP50 genotyped animals, and subsequently imputed to HD using a reference population of 974 Irish Holstein-Friesian HD genotyped animals. After imputation, all 589 cows had 636,471 SNP with a minor allele frequency $>0.01$ for analysis.

\section{Statistical Analyses}

Data were analyzed using SAS version 9.4 (SAS Institute Inc., Cary, NC). The descriptive statistics and normality for serum AMH concentrations $(\mathrm{pg} / \mathrm{mL})$ were first determined in all 647 cows using the UNIVARIATE procedure.

To identify factors associated with serum AMH concentrations (dependent continuous variable), a multivariable model including herd $(\mathrm{A}, \mathrm{B}, \mathrm{C}, \mathrm{D}, \mathrm{E}$, $\mathrm{F}$, and $\mathrm{G}$ ), lactation number (first, second, third, and $\geq$ fourth lactations), precalving BCS (categorized as high and low BCS; $>3.00$ and $\leq 3.00$, respectively), week postpartum (first and second week), and season of blood sampling (fall, spring, summer, and winter) were used to explain the variability observed in serum AMH concentration by ANOVA method using the MIXED procedure in a subset of 460 cows that had a complete data available on the aforesaid explanatory variables studied. In addition, contrast statements were constructed to test linear, quadratic, and cubic effects of lactation number on serum AMH concentrations. Data pertaining to serum AMH concentrations were first transformed by Box-Cox data transformation to meet the assumptions for a Gaussian distribution. The serum concentrations of AMH (transformed values) were initially modeled against all of the aforementioned categorical variables and their interactions. As none of the interactions was significant, the final model only had the categorical variables modeled against serum AMH concentrations, and the differences in means were tested using the Tukey-Kramer multiple means comparison test. The reported results are back-transformed for ease of interpretation.

The optimum AMH threshold predictable of $\mathrm{P} / \mathrm{AI}$, including sensitivity and specificity, was first determined in 563 cows that had $\mathrm{P} / \mathrm{AI}$ data available using the receiver operating characteristic (ROC) curve analysis. A priori power analysis based on type I error of 0.05 , power of 0.80 , and an allocation ratio of $1: 2$ (assuming only one-third of cows become pregnant to the first AI) to obtain an area under the curve of 0.60 called for only 219 cows in total to attain statistical significance. The ROC curves analyze sensitivity and 1 - specificity. Sensitivity is the proportion of cows above the optimum $\mathrm{AMH}$ threshold diagnosed as pregnant to first AI, and specificity is the proportion of cows below the optimum AMH threshold diagnosed as not pregnant to first AI. The optimum AMH threshold was chosen based on the highest Youden's J statistic index. The significance of the optimum AMH threshold was determined based on the area under the curve (AUC), where the AUC ranged from 0.50 to 1.00 , with AUC of 0.50 considered noninformative and the AUC of 1.00 considered perfect as previously described (Swets, 1988).

A subset of 460 cows that had a complete data set available for both reproductive outcomes and all explanatory variables were ranked across herds in an ascending order by serum AMH concentrations and grouped into low AMH (lowest $20 \%$ values; $\mathrm{n}=92$; mean $=56.6$; range $=13.9$ to $81.7 \mathrm{pg} / \mathrm{mL})$, intermediate $\mathrm{AMH}$ (intermediate $60 \%$ values; $\mathrm{n}=276$; mean $=$ 164.6 ; range $=83.8$ to $284.9 \mathrm{pg} / \mathrm{mL}$ ), or high $\mathrm{AMH}$ (highest $20 \%$ values; $\mathrm{n}=92$; mean $=420.1$; range $=$ 287.4 to $1,879.0 \mathrm{pg} / \mathrm{mL}$ ) categories. Cows were ranked across herds as there was no overall effect of herd on variation in serum $\mathrm{AMH}$ concentrations, and one of the objectives of the study was to establish a common cutoff across herds. In addition, the categories were chosen to mimic the proposed importance of ovarian reserve for fertility (Ireland et al., 2011) and to take an approach similar to that of Ribeiro et al. (2014).

The associations among categories of serum AMH (low AMH, intermediate AMH, and high $\mathrm{AMH}$ ), type of AI (IDE and timed AI), herd (A, B, C, D, E, F, and G), parity (primiparous and multiparous), precalving BCS (categorized as high and low BCS; $>3.00$ and $\leq 3.00$, 
respectively), postcalving BCS (categorized as high and low BCS; $>2.75$ and $\leq 2.75$, respectively), and 305-d MEQ milk yield (categorized as high and low MEQ milk yield based on mean 305-d MEQ milk yield within each herd) and P/AI or PLOSS were analyzed using the GLIMMIX procedure, whereas the model specifications included a binomial distribution and logit function, and an option to retrieve odds ratios and their confidence intervals. The $\mathrm{P} / \mathrm{AI}$ or PLOSS was initially modeled against all of the aforementioned categorical variables and their interactions. As none of the interactions was significant, the final model included only the categorical variables and tested against $\mathrm{P} / \mathrm{AI}$ or PLOSS. The mean 305-d MEQ milk yield was 12,197, 11,349, 13,686, $9,858,11,031,11,502$, and $12,387 \mathrm{~kg}$ for herds A to G, respectively, and the overall mean milk production for all cows was 11,092 kg.

The differences in intervals from calving to pregnancy risk up to $250 \mathrm{~d}$ postpartum between categories of serum AMH were evaluated using the Kaplan-Meier Survival analysis (LIFETEST procedure). The results from Kaplan-Meier survival analysis were confirmed by a Cox proportional hazard model (PHREG procedure). Significant differences were reported if $P \leq 0.05$ and considered to be a tendency if $P>0.05$ and $\leq 0.10$.

\section{GWAS and Estimation of Genomic Heritability for AMH}

Whole genome association analysis was performed in genome-wide complex trait analysis (Yang et al., 2011) using a mixed linear model-based association analysis based on the leave-one-chromosome-out method (Yang et al., 2014), across all 589 genotyped animals. This approach accounts for population substructure and relatedness through the construction of genomic relationship matrixes. The following model was used for analysis:

$$
y=\mu+\mathbf{b x}+g^{-}+e,
$$

where $y$ is the Box-Cox transformed AMH dependent variable, $\mu$ is the overall mean, $\mathbf{b}$ is a vector of fixed effects including herd and the additive effect of the candidate SNP tested for association, $\mathbf{x}$ is the incidence matrix for the parameters $b, g^{-}$is the accumulated polygenic effect of all SNP except those on the chromosome where the candidate SNP is located, and $e$ is the residual. False discovery rate control was performed using the Benjamini-Hochberg method using a false discovery rate of 0.05. Gene search was done using Ensembl (http://ensembl.org/) and National Center for Biotechnology Information map viewer (http://www .ncbi.nlm.nih.gov/mapview/) on the UMD 3.1 genome build. The relative roles of nearest candidate genes were searched using both the Bovine Genome Database (http://bovinegenome.org/) and Human Genome Database (http://www.genecards.org/). In addition, the proportion of phenotypic variance accounted for by all SNP (SNP-based heritability/genomic heritability) was estimated using the genomic REML approach in genome-wide complex trait analysis (Yang et al., 2010). To ensure the genomic heritability estimate was not inflated due to close familial relationships, all animals with an estimated coefficient of relatedness of $>0.125$ were removed $(\mathrm{n}=391)$ before estimation.

\section{RESULTS AND DISCUSSION}

The overall mean $( \pm$ SEM $)$, median, minimum, and maximum serum AMH concentrations were $191.1 \pm$ $6.3,151.7,13.9$, and $1,879.0 \mathrm{pg} / \mathrm{mL}$, respectively. The circulating concentrations of AMH were highly variable among cows in the current study (Figure 1) as reported in previous studies (Monniaux et al., 2012; Ribeiro et al., 2014; Gobikrushanth et al., 2017). The variation in circulating $\mathrm{AMH}$ were reported to be associated with maternal nutritional status, species, breed, and lactation number in cattle (Mossa et al., 2013; Batista et al., 2014; Ribeiro et al., 2014). In this regard, Mossa et al. (2013) showed that female calves of dams that had been nutritionally restricted from $11 \mathrm{~d}$ before AI up to d 110 of gestation had lower circulating $\mathrm{AMH}$ concentrations from 4 mo to $1.8 \mathrm{yr}$ of age compared with control calves born to mothers that had no nutritional restriction imposed during gestation ( $\sim 180$ vs. $280 \mathrm{pg} / \mathrm{mL}$ ). Batista et al. (2014) reported that Bos indicus heifers had greater circulating AMH than Bos taurus heifers (930 vs. 300 pg/mL). Moreover, Ribeiro et al. (2014) found that Jersey and Holstein $\times$ Jersey crossbred cows had greater plasma AMH concentrations than Holstein cows (337 and 298 vs. $264 \mathrm{pg} / \mathrm{mL}$ ) and that second- and third-lactation cows (irrespective of breed) had higher plasma AMH than those of first and fourth lactation (342 and 328 vs. 257 and $273 \mathrm{pg} /$ $\mathrm{mL}$, respectively).

In the present study, none of the nongenetic factors evaluated were associated with serum concentrations of AMH in dairy cows (Figure 2). Although there was no overall herd effects on the variation in serum $\mathrm{AMH}$ concentrations (Figure 2A; $P=0.25$ ), it was greater for herd $\mathrm{F}$ compared with herd $\mathrm{B}(P=0.03)$, but the exact reason underpinning this difference is unknown. It is plausible, however, that genetic variation among cows both within and between herds for circulating AMH might have been a contributory factor. A quadratic relationship between serum AMH concentrations and 


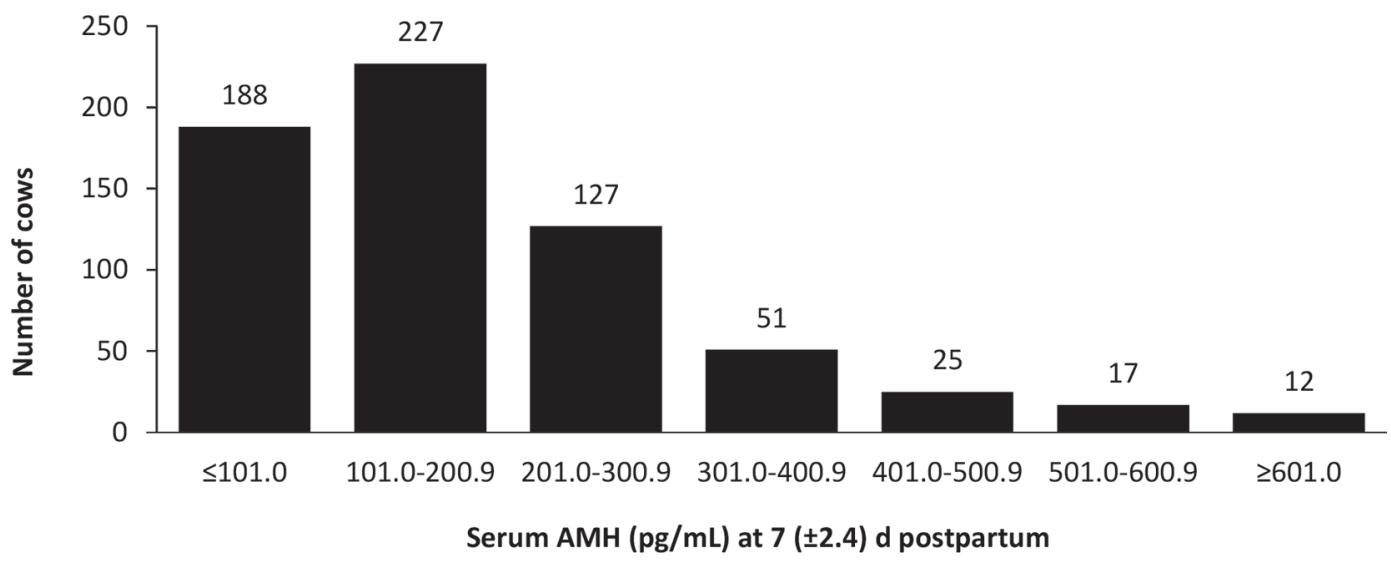

Figure 1. The distribution of serum anti-Müllerian hormone $(\mathrm{AMH})$ concentrations at $7( \pm 2.4)$ d postpartum in all 647 lactating Holstein cows. The lowest and highest serum AMH concentrations were 13.9 and $1,879.0 \mathrm{pg} / \mathrm{mL}$, respectively.

lactation number was observed in the current study $(P$ $<0.01$; Figure 2B). This is consistent with previous observations of circulating AMH and lactation number in dairy cows (Ribeiro et al., 2014) or between AFC and age in beef heifers and dairy cows (Cushman et al., 2009, and Mossa et al., 2012, respectively). Collectively, these results support the hypothesis that circulating concentrations of AMH increase with greater ovarian follicular recruitment up to $5 \mathrm{yr}$ of age (or third parity) and then decline following gradual depletion of the ovarian reserve. In addition, we found that precalving BCS, postpartum week or season of blood sampling did not influence serum AMH concentrations in dairy cows (Figure 2C, 2D, and 2E). Monniaux et al. (2012) reported that $\mathrm{AMH}$ concentrations were quite stable when repeatedly measured in a same set of cows at $8,18,28,38$, and $48 \mathrm{~d}$ postpartum, despite marked changes in energy balance status. Therefore, for a given species, breed, or lactation number, circulating AMH concentrations do not appear to be influenced by some of the common explanatory variables used in reproductive studies such as BCS, week postpartum, and season.

As mentioned elsewhere, if a positive association exists between AMH and reproductive outcomes and an optimum AMH threshold could be established, it will assist dairy producers to make economically beneficial decisions by selectively breeding cows with high AMH to improve reproductive efficiency of dairy herds. Therefore, we proposed to identify the optimum circulating $\mathrm{AMH}$ threshold that was predictive of $\mathrm{P} / \mathrm{AI}$. Using ROC curve analysis, however, the association between serum $\mathrm{AMH}$ and $\mathrm{P} / \mathrm{AI}$ was not significant $(P=$ $0.72 ; \mathrm{n}=563)$; consequently, the optimum circulating AMH threshold, including its sensitivity and specificity, that could predict $\mathrm{P} / \mathrm{AI}$ was not established. A previous report by Baruselli et al. (2015) also failed to detect any association between circulating $\mathrm{AMH}$ and age at conception in 528 nulliparous heifers or the interval from calving to conception in 223 Nelore cows (Bos indicus). Collectively, these findings suggest that the use of circulating $\mathrm{AMH}$ as a predictor of fertility outcomes in cattle seems unrealistic.

The role of $\mathrm{AMH}$ on reproductive function is poorly understood, and therefore the exact mechanisms linking AMH to fertility, if any, are unknown. A recent review by Dewailly et al. (2014) suggested that AMH plays 2 major functions in women: (1) inhibition of follicular growth from the primordial follicle reserve, averting premature exhaustion of the ovarian follicular reserve; and (2) reduction in the responsiveness to FSH of preantral and small antral follicles, restricting ovarian follicular growth. Nevertheless, the relative importance of these specific functions of $\mathrm{AMH}$ on fertility is not clear. Ribeiro et al. (2014) was the first to report that cows (a combination of Holstein, Jersey, and Holstein $\times$ Jersey crossbreds) with low $(\leq 140.0)$, intermediate $(>140.0$ to $\leq 450.0)$, and high $(>451.0)$ plasma AMH concentrations $(\mathrm{pg} / \mathrm{mL})$ did not differ in $\mathrm{P} / \mathrm{AI}$ following a timed AI event; however, some evidence indicated that cows in the low AMH category had greater embryo mortality after timed AI, and had lower likelihood of pregnancy establishment after subsequent spontaneous estrus (AI and natural service). Moreover, Jimenez-Krassel et al. (2015) found no association between serum AMH concentrations (categorized into quartiles) in 11- to 15-mo-old Holstein heifers and subsequent measures of reproductive success as heifers and as lactating cows (conception rate at first AI, days open, calving interval, and services per conception). Of note, however, Jimenez-Krassel et al. (2015) reported that the total percentage of lactating cows that became pregnant across parities 1 to 3 combined was significantly lower 
for cows in the first quartile compared with those in the second or third quartiles, but was not different from cows in the fourth quartile. In the present study, P/AI
$(34,43$, and $40 \% ; P=0.37)$ and pregnancy risk up to 250 d postpartum were similar among low, intermediate, and high AMH cows subjected either timed AI or

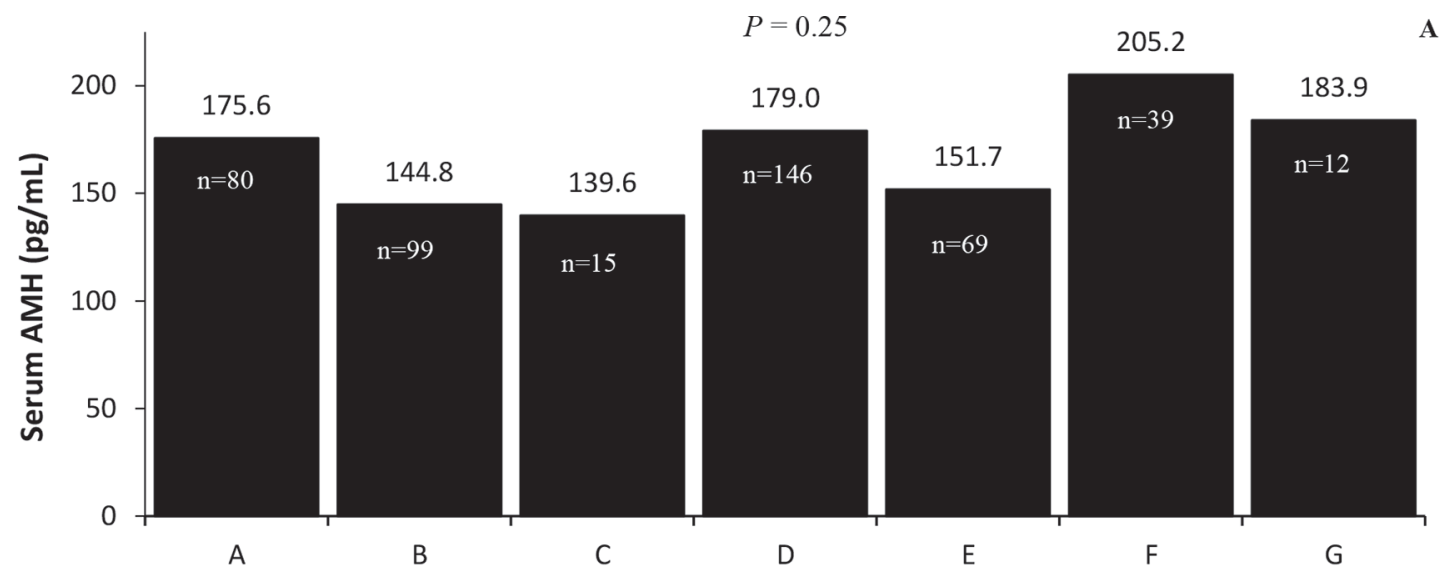

Herd
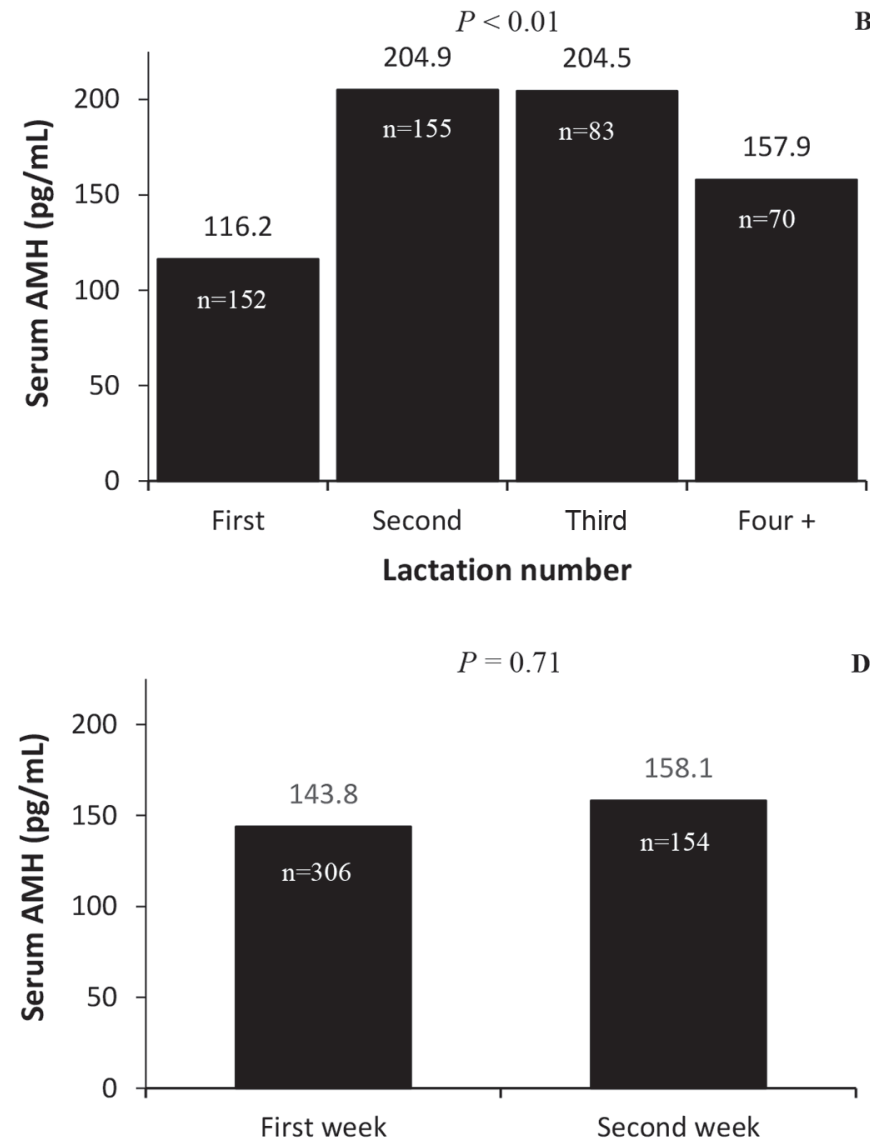

Week of AMH blood sampling postpartum
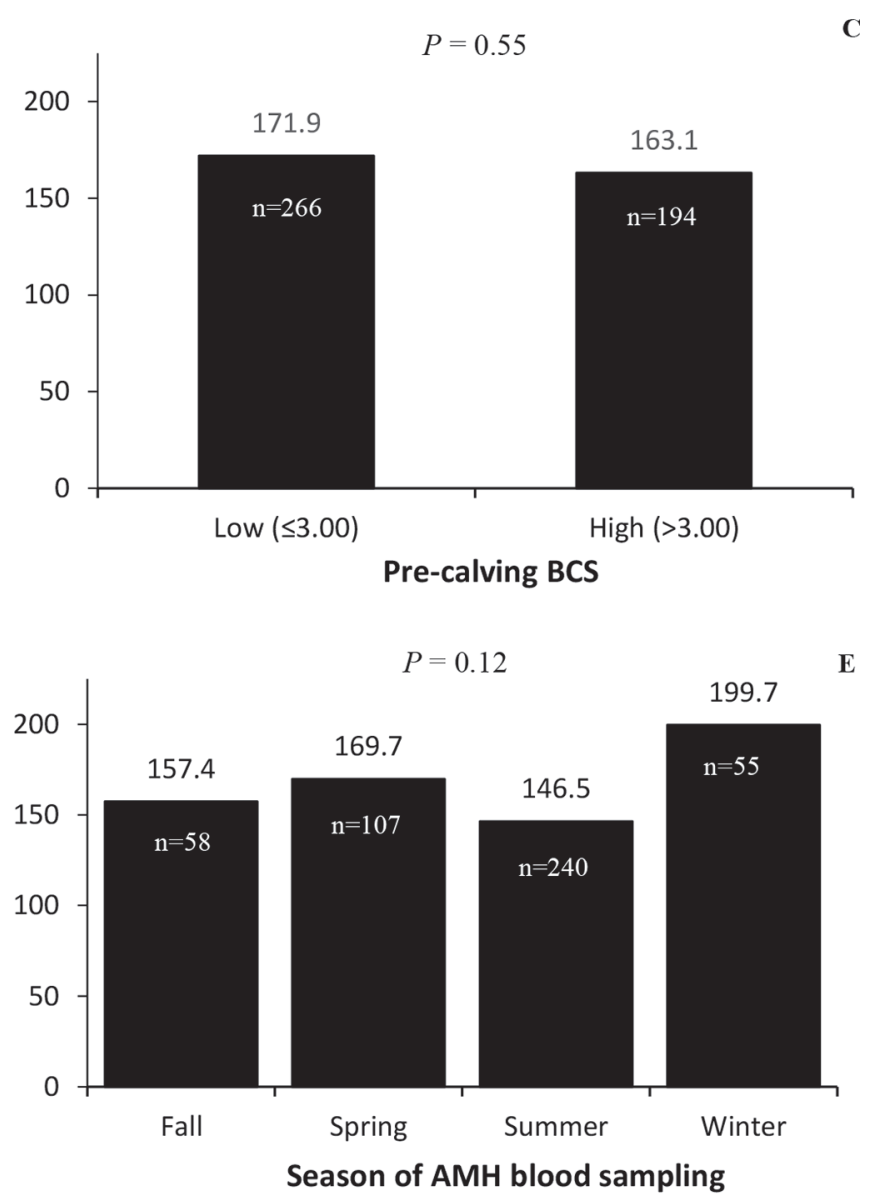

Figure 2. The associations among herd, lactation number, precalving BCS, week postpartum, season, and serum anti-Müllerian hormone $(\mathrm{AMH})$ concentrations at $7( \pm 2.4)$ d postpartum in a subset of 460 lactating Holstein cows (A, B, C, D, and E, respectively). The serum concentrations of AMH (transformed values) were back transformed for ease of interpretation. 
Table 1. Associations among categories of serum anti-Müllerian hormone (AMH), type of AI, herd, parity, pre- and postcalving BCS, 305-d mature-equivalent (MEQ) milk yield, and pregnancy to first AI (P/AI) in a subset of 460 Holstein cows

\begin{tabular}{|c|c|c|c|c|}
\hline Variable & $\begin{array}{l}\mathrm{LSM} \text { for P/AI, \% } \\
\text { (no./no.) }\end{array}$ & $\begin{array}{l}\text { Odds ratio } \\
\text { estimate }\end{array}$ & $95 \% \mathrm{CI}$ & $P$-value \\
\hline \multicolumn{5}{|l|}{$\mathrm{AMH}_{\text {category }}{ }^{1}$} \\
\hline High & $40.2(36 / 92)$ & 1.29 & $0.67-2.47$ & \multirow[t]{3}{*}{0.37} \\
\hline Intermediate & $43.2(113 / 276)$ & 1.46 & $0.86-2.49$ & \\
\hline Low & $34.2(30 / 92)$ & Reference & & \\
\hline \multicolumn{5}{|l|}{ Type of $\mathrm{AI}^{2}$} \\
\hline IDE & $38.4(63 / 164)$ & 0.97 & $0.65-1.43$ & \multirow[t]{2}{*}{0.87} \\
\hline TAI & $39.2(116 / 296)$ & Reference & & \\
\hline \multicolumn{5}{|l|}{ Herd } \\
\hline A & $48.0(40 / 80)$ & 0.72 & $0.20-2.61$ & \multirow[t]{7}{*}{0.16} \\
\hline B & $39.4(37 / 99)$ & 0.51 & $0.14-1.82$ & \\
\hline $\mathrm{C}$ & $20.0(3 / 15)$ & 0.19 & $0.03-1.12$ & \\
\hline $\mathrm{D}$ & $37.0(54 / 146)$ & 0.51 & $0.14-1.84$ & \\
\hline $\mathrm{E}$ & $29.0(20 / 69)$ & 0.33 & $0.09-1.20$ & \\
\hline $\mathrm{F}$ & $48.7(19 / 39)$ & 0.70 & $0.18-2.70$ & \\
\hline G & $50.0(6 / 12)$ & Reference & & \\
\hline \multicolumn{5}{|l|}{ Parity } \\
\hline Multiparous & $33.4(106 / 308)$ & 0.61 & \multirow[t]{2}{*}{$0.39-0.95$} & \multirow[t]{2}{*}{0.03} \\
\hline Primiparous & $45.2(73 / 152)$ & Reference & & \\
\hline \multicolumn{5}{|l|}{ Precalving $\mathrm{BCS}^{3}$} \\
\hline High $(>3.00)$ & $40.2(78 / 194)$ & 0.93 & \multirow[t]{2}{*}{$0.55-1.56$} & \multirow[t]{2}{*}{0.79} \\
\hline Low $(\leq 3.00)$ & $38.0(101 / 266)$ & Reference & & \\
\hline \multicolumn{5}{|l|}{ Postcalving $\mathrm{BCS}^{3}$} \\
\hline High $(>2.75)$ & $46.7(85 / 185)$ & 1.54 & \multirow[t]{2}{*}{$0.93-2.56$} & \multirow[t]{2}{*}{0.09} \\
\hline Low $(<2.75)$ & $34.2(94 / 275)$ & Reference & & \\
\hline \multicolumn{5}{|c|}{ 305-d MEQ milk yield ${ }^{4}(\mathrm{~kg})$} \\
\hline $\operatorname{High}(>11,092)$ & $33.3(79 / 237)$ & 0.77 & \multirow[t]{2}{*}{$0.50-1.17$} & \multirow[t]{2}{*}{0.21} \\
\hline Low $(\leq 11,092)$ & $44.8(100 / 223)$ & Reference & & \\
\hline
\end{tabular}

${ }^{1} \mathrm{AMH}$ category: the mean and range of serum $\mathrm{AMH}$ concentrations $(\mathrm{pg} / \mathrm{mL})$ for cows grouped into low (mean $=56.6$; range $=13.9$ to 81.7$)$, intermediate $($ mean $=164.6$; range $=83.8$ to 284.9$)$, and high AMH $($ mean $=$ 421.4 ; range $=287.4$ to $1,879.0)$ categories.

${ }^{2}$ Type of AI: cows were inseminated at detected estrus (IDE) or received timed AI (TAI) following synchronization of ovulation.

${ }^{3}$ Categories of precalving BCS (determined between 1 and 2 wk before calving) and postcalving BCS (determined between 4 and 6 wk after calving) were based on precalving BCS of 3.00 and postcalving BCS of 2.75.

${ }^{4}$ Cows were categorized as high or low if 305-d MEQ milk yield was $>$ or $\leq$ the mean within each herd, respectively. Overall mean across herds was 11,092 kg.

IDE (Table 1 and Figure 3, respectively). Although no statistical significance was detected, cows IDE that had low serum AMH concentrations had P/AI that was 8 to $10 \%$ lower than cows with intermediate or high serum AMH concentrations $(24,32$, and $34 \% ; P=0.57)$. Therefore, future studies should focus on the evaluation of circulating $\mathrm{AMH}$ and fertility in a larger population of dairy cows inseminated at detected estrus to further test the favorable relationship between circulating AMH concentrations and fertility reported herein and by others (Ribeiro et al., 2014; Jimenez-Krassel et al., 2015).

Similar to the lack of associations reported between serum AMH categories and pregnancy establishment (i.e., $\mathrm{P} / \mathrm{AI}$ or pregnancy risk up to $250 \mathrm{~d}$ postpartum), PLOSS also not differ between low, intermediate, and high AMH categories (20 vs. 12 and 8\%, respectively, $P=0.38$ ). This was likely because only a small proportion of cows that became pregnant to first AI contrib- uted toward PLOSS data under each AMH categories [low $\mathrm{AMH}=(6 / 30)$, intermediate $\mathrm{AMH}=(14 / 113)$, and high $\mathrm{AMH}=(3 / 36)]$. In this regard, Ribeiro et al. (2014) found significantly greater pregnancy losses in cows with low plasma AMH concentrations compared with cows with intermediate or high plasma AMH concentrations (17 vs. 9 and 8\%, respectively) and suggested that the greater pregnancy losses observed for cows with low circulating AMH concentration may be at least in part explained by the low-AFC (presumed to have low $\mathrm{AMH}$ ), low-progesterone model initially proposed by Jimenez-Krassel et al. (2009). Therefore, the preliminary results on the association between AMH and embryo survival in the current and previous (Ribeiro et al., 2014) studies, and the molecular mechanisms underlying this association warrants further investigation in dairy cows.

The genomic heritability of AMH and a GWAS identifying potential QTL associated with phenotypic varia- 
tion in $\mathrm{AMH}$ concentrations are novel aspects yet to be explored in dairy cows. In a preliminary report, Nawaz et al. (2017) estimated a genomic heritability of 0.36 for circulating AMH concentrations using 2,914 Holstein dairy heifers. A slightly greater genomic heritability of $0.46(\mathrm{SE}=0.31)$ was estimated in the present study; however, caution should be taken when interpreting such a result due to large standard error and small sample size $(\mathrm{n}=198)$ used in the heritability estimation after excluding 391 cows that had close familial relationships out of 589 cows genotyped. Interestingly, the moderate heritability estimate reported for circulating $\mathrm{AMH}$ in the current study and that of Nawaz et al. (2017) were quite comparable to the heritability estimate of 0.31 reported for AFC in dairy cows (Walsh et al., 2014). In total, $670 \mathrm{SNP}$ across $12 \mathrm{BTA}$ were significantly associated with variation in serum AMH concentration after adjustment for multiple testing (Figure 4). The list of nearest candidate genes identified for each significant lead SNP from their respective chromosomes and the major proteins encoded by those candidate genes are listed in Table 2. Only candidate genes that were related to $\mathrm{AMH}$ and fertility are discussed below. The strongest association $(P=1.58 \times$ $10^{-8} ; \mathrm{q}=6.92 \times 10^{-5}$, where $\mathrm{q}$ is the adjusted $P$-value after controlling for false discovery rate of $<0.05)$ on BTA7 (rs43505499) was located $15.51 \mathrm{~kb}$ upstream of the $A M H$ gene, suggesting that variants within $A M H$ or perhaps regulatory regions of this gene are associated with the variability in circulating AMH concentrations. This is further substantiated by the significant association of the upstream $A M H$ variant rs43505519 ( $P=$ $\left.1.49 \times 10^{-7} ; \mathrm{q}=4.27 \times 10^{-4}\right)$. Further fine mapping of this genomic region is required to identify the causal variants affecting AMH production. In the interim, however, this QTL could be used to identify heifers and cows as potential donors for future superovulation programs.

The strongest associations with AMH variation were located on BTA11, where 513 SNP within a 14-Mb region remained significantly associated after adjustment for multiple testing. Several putative candidate genes were identified within close proximity $(<200 \mathrm{~kb})$ of the strongest association (rs109286956) including SCAI and PPP6C. Indeed, 3 of the 5 strongest associations on BTA11 (rs109629605, rs109469337, and rs109162401) were located within regulatory regions of PPP6C, which has been recently described as indispensable for mouse embryogenesis after implantation; mice lacking the Ppp6c phosphatase domain showed

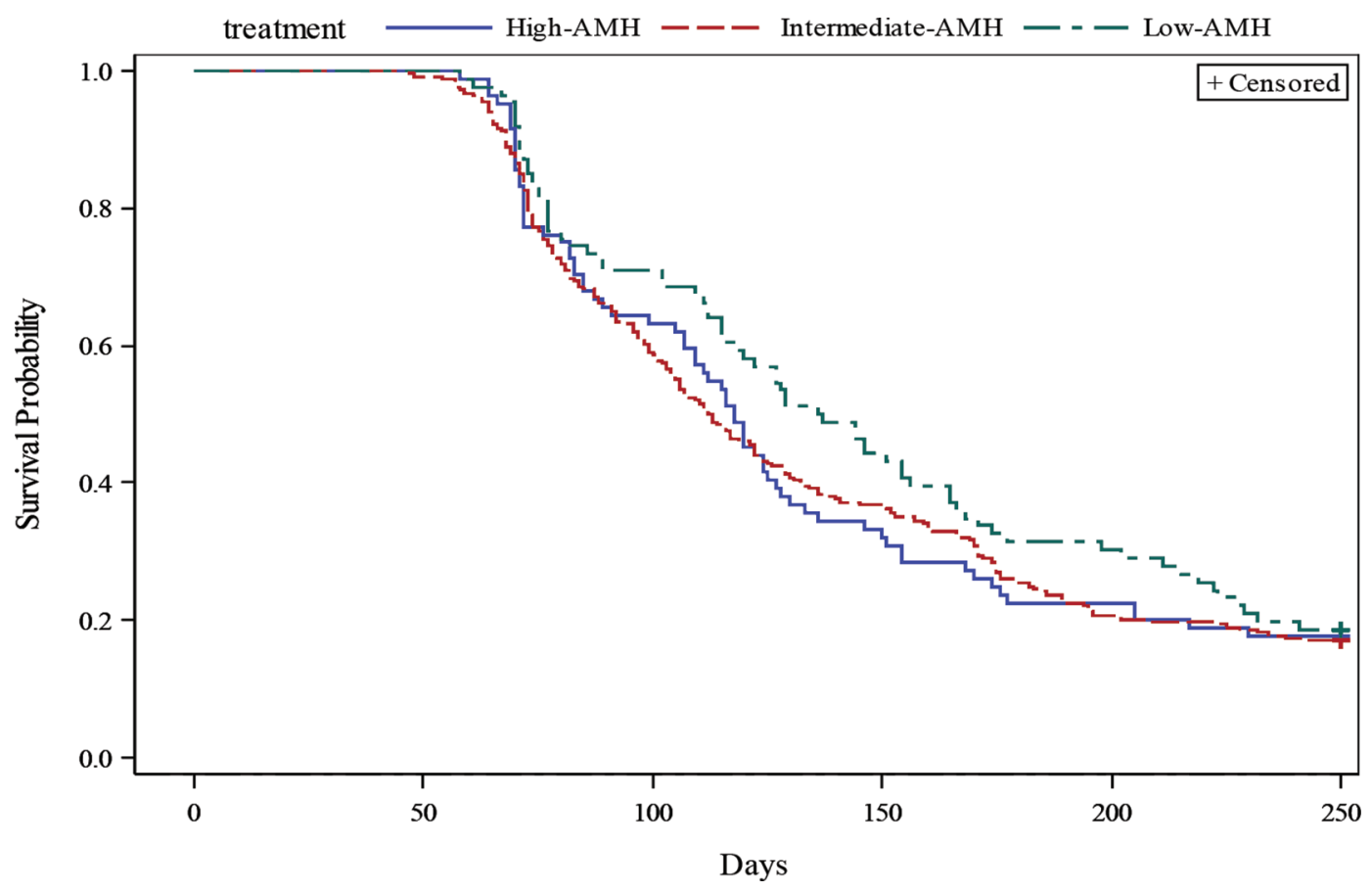

Figure 3. Kaplan-Meier survival curve illustrating the probability of pregnancy risk up to $250 \mathrm{~d}$ postpartum based on anti-Müllerian hormone $(\mathrm{AMH})$ concentrations $(\mathrm{pg} / \mathrm{mL})$ in serum categorized as low $($ mean $=56.6 ;$ range $=13.9$ to $81.7 ; \mathrm{n}=92)$, intermediate $($ mean $=164.6 ;$ range $=$ 83.8 to $284.9 ; \mathrm{n}=276$ ), or high $\mathrm{AMH}$ (mean $=421.4$; range $=287.4$ to $1,879.0 ; \mathrm{n}=92$ ) in a subset of 460 lactating Holstein cows. The overall likelihood of pregnancy by $250 \mathrm{~d}$ postpartum did not differ between categories of AMH $(P=0.44)$. The hazard of pregnancy risk up to $250 \mathrm{~d}$ postpartum did not differ between cows in the high and low AMH categories (hazard ratio $=1.18$; CI: $0.85-1.65 ; P=0.33$ ). Likewise, it did not differ between cows in the intermediate and low AMH categories (hazard ratio $=1.19$; CI: $0.91-1.56 ; P=0.21$ ). Color version available online. 


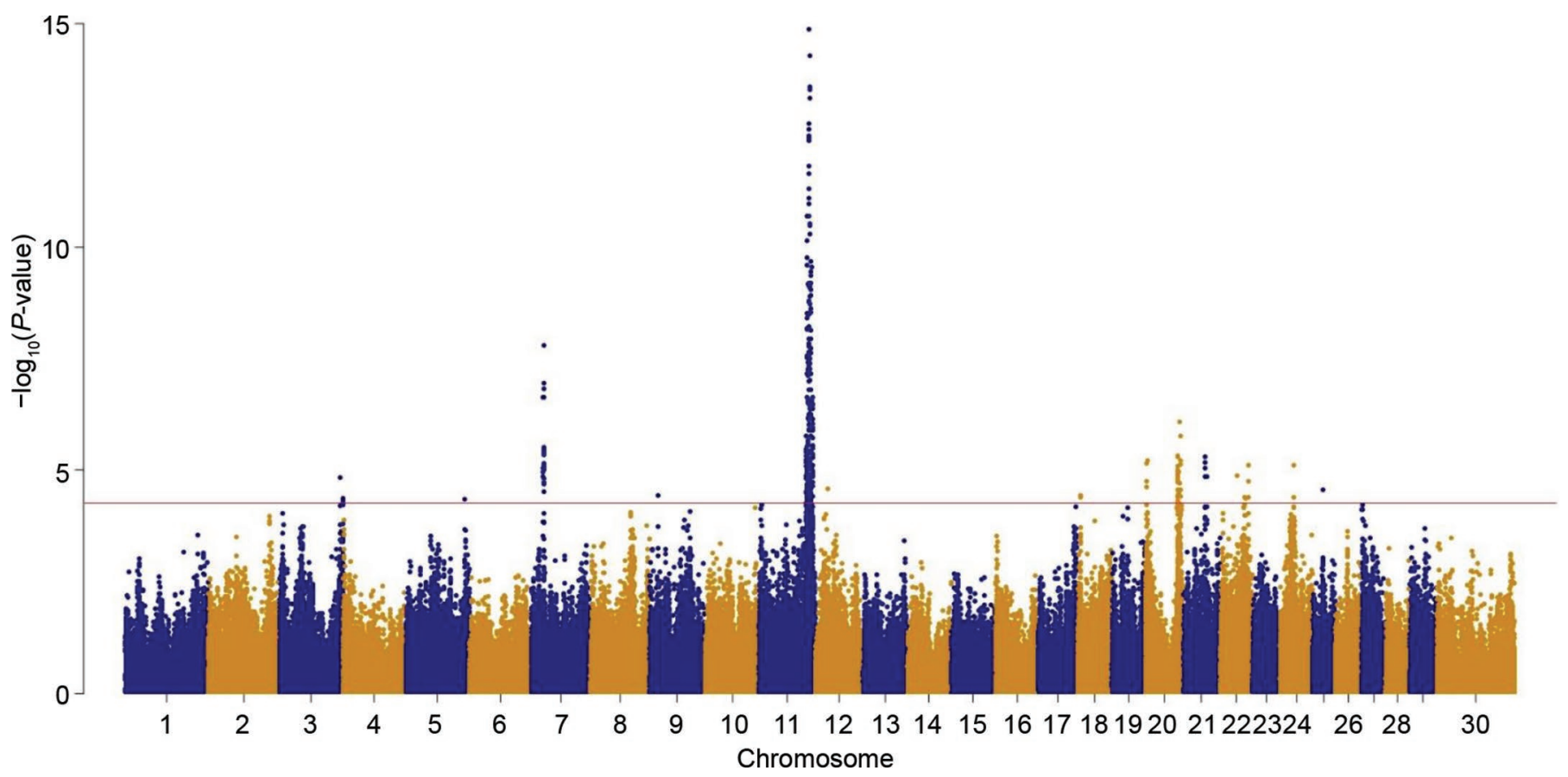

Figure 4. Manhattan plot of the genome-wide association $P$-values for transformed serum anti-Müllerian hormone concentrations across 589 genotyped lactating Holstein cows. The horizontal line indicates significant SNP identified across 12 BTA (BTA3, 5, 7, 9, 11, 12, 18, 20, 21, 22, 24 , and 25) after adjusting for a false discovery rate of $<0.05$. Color version available online.

clear developmental defects after implantation and no viable pups were born (Ogoh et al., 2016). In addition, $S C A I$ deficiency has also been associated with subfertility in mice, whereby $S C A I$-deficient mice were found to contain few or no developing primary follicles and showed a 7 -fold reduction in fertility rates in comparison to controls (Hansen et al., 2016).

Furthermore, the candidate genes FGF18 and EEF2K identified on BTA20 and BTA25, respectively, have also been related to embryonic development in mice (Ohbayashi et al., 2002; Chu et al., 2014). The strongest association on BTA20, rs110249317 (at $3.1 \mathrm{Mb}$ ), was an intronic variant within the candidate gene FGF18. This gene encodes the member of the fibroblast growth factor family that is known to be involved in a variety of biological processes, including embryonic development, cell growth, morphogenesis, tissue repair, tumor growth, and invasion (Ornitz and Itoh, 2015). Ohbayashi et al. (2002) reported that deletion of the FGF18 gene affected skeletal development in mice embryos by reducing the proliferation of osteogenic mesenchymal cells and terminal differentiation of osteoblasts in the calvarial bone. Similarly, the lead SNP rs137098518 (at $20.1 \mathrm{Mb}$ ) on BTA25 is an intronic variant within the candidate gene EEFRK and encodes a highly conserved protein kinase enzyme, which plays a key role in the calmodulin-mediated signaling pathway that links activation of cell surface receptors to cell division (Berch- told and Villalobo, 2014). Deletion of the gene EEF2K in mice has been shown to result in reduced ovarian apoptosis, with consequent accumulation of aberrant follicles and defective oocytes at advanced reproductive age (Chu et al., 2014). Perhaps, numerically fewer pregnancy losses observed in cows with high circulating $\mathrm{AMH}$ in the present study could be at least partially explained by the functions of the above 4 candidate genes that are in linkage disequilibrium with genetic markers identified for variation in circulating $\mathrm{AMH}$ concentration. However, these genomic associations would require validation in dairy cows. In addition, it is important that we recognize that fertility is a highly polygenic trait under the control of thousands of SNP effects (Minozzi et al., 2013) and these candidate genes are some of many that contribute marginally to the phenotypic variance.

In summary, we identified 4 main results: (1) serum AMH concentrations were not associated with herd, precalving BCS, postpartum week, and season of sampling, but lactation number had a quadratic relationship with serum AMH concentrations; (2) an optimum circulating $\mathrm{AMH}$ threshold predictive of $\mathrm{P} / \mathrm{AI}$ could not be established; (3) categories of serum AMH had no associations with $\mathrm{P} / \mathrm{AI}$, PLOSS, or pregnancy risk up to $250 \mathrm{~d}$ postpartum; and (4) one candidate gene associated with $\mathrm{AMH}$ production $(A M H$ gene on BTA7) and 4 candidate genes related to embryo development 
GOBIKRUSHANTH ET AL.

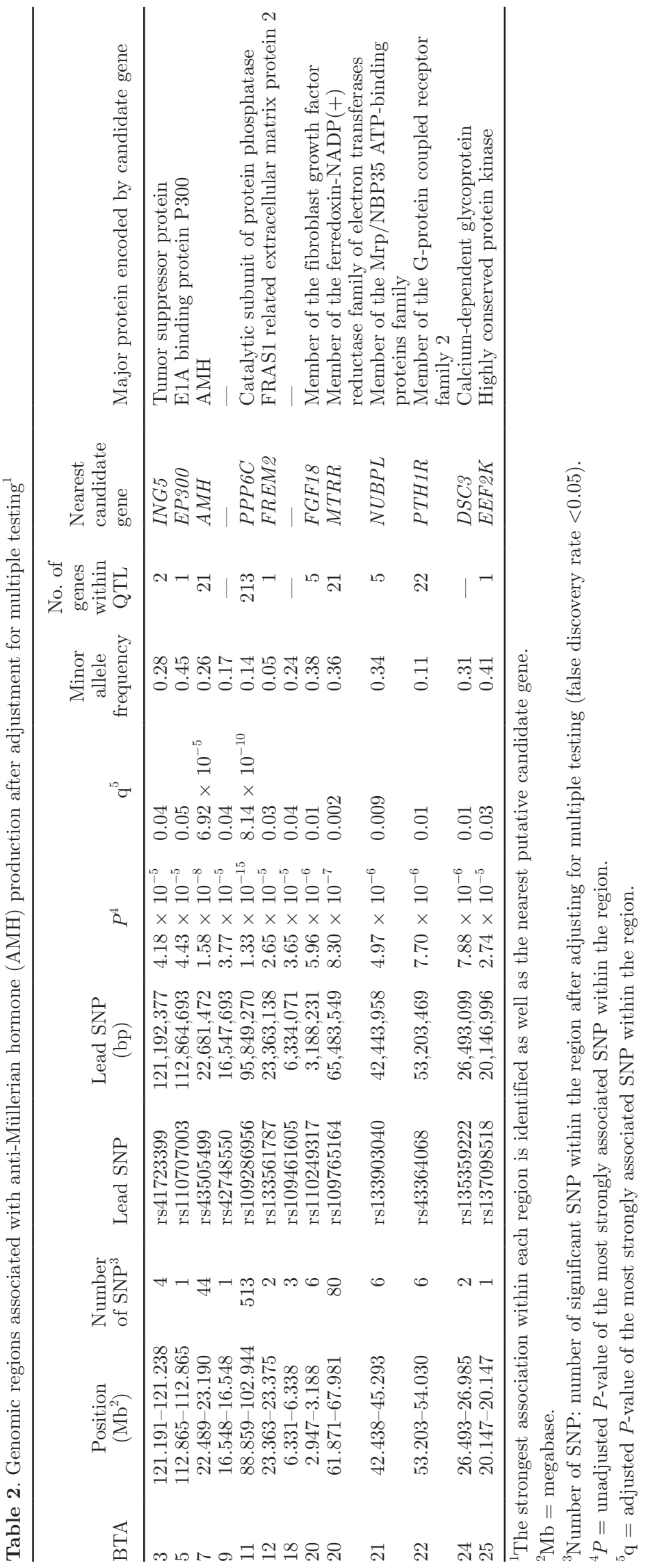


(SCAI and PPP6C genes on BTA11 and FGF18 and EEF2K genes on BTA20 and BTA25, respectively) were in linkage disequilibrium with SNP associated with phenotypic variation in serum AMH in dairy cows.

\section{ACKNOWLEDGMENTS}

This project was financially supported in part by Growing Forward 2, a federal-provincial-territorial initiative (Research Opportunities and Innovation-Internal Initiatives Projects \# DA7642064 and MC4234670). We thank Alberta Livestock and Meat Agency (Grant \#2016F056R) and Alberta Milk (Edmonton, Canada) for supporting parts of this research. M. Gobikrushanth is a recipient of the Teagasc-University of Alberta Walsh Fellowship sponsored by Alberta Innovates Biosolutions (Edmonton, Canada). We acknowledge Ansh Labs (Webster, TX) for their in-kind contribution of discounted pricing on AMH assays. The authors thank Amir Behrouzi and Courtney Felton of the Livestock Research and Extension Branch, Alberta Agriculture and Forestry (Edmonton, Canada); Irene LopezHelguera, visiting scientist from University of Lleida, Spain; and Tianfu Yang, Tony Bruinje, Patricia Dutra, Rohanna Wang, and Ashley L'Hirondelle of University of Alberta (Edmonton, Canada) for their assistance during the study. The authors thank the staff of the Dairy Research and Technology Centre, University of Alberta (Edmonton, Canada), the owners of the commercial dairy farms (Breevliet Ltd., Wetaskiwin; Enterprises Lavoie Inc., St. Isidore; Five Star Cattle Company, Lacombe; Tuxedo Farms, Westlock; Vanden Dool Farms, Picture Butte; Yoke Farm Ltd., Westlock) and the herd veterinarians for their cooperation and participation.

\section{REFERENCES}

Baruselli, P. S., E. O. S. Batista, L. M. Vieira, and A. H. Souza. 2015. Relationship between follicle population, AMH concentration and fertility in cattle. Anim. Reprod. 12:487-497.

Batista, E. O. S., G. G. Macedo, R. V. Sala, M. Ortolan, M. F. Sá Filho, T. A. Del Valle, E. F. Jesus, R. Lopes, F. P. Rennó, and P. S. Baruselli. 2014. Plasma anti-Mullerian hormone as a predictor of ovarian antral follicular population in Bos indicus (Nelore) and Bos taurus (Holstein) heifers. Reprod. Domest. Anim. 49:448-452.

Berchtold, M. W., and A. Villalobo. 2014. The many faces of calmodulin in cell proliferation, programmed cell death, autophagy, and cancer. Biochim. Biophys. Acta 1843:398-435.

Canadian Council on Animal Care. 2009. Guidelines on the Care and Use of Farm Animals in Research, Teaching and Testing. Accessed Oct. 14, 2014. http://ccac.ca/Documents/Standards/Guidelines/ Farm_Animals.pdf.

Chu, H. P., Y. Liao, J. S. Novak, Z. Hu, J. J. Merkin, Y. Shymkiv, B. P. Braeckman, M. V. Dorovkov, A. Nguyen, P. M. Clifford, R. G. Nagele, D. E. Harrison, R. E. Ellis, and A. G. Ryazanov. 2014. Germline quality control: eEF2K stands guard to eliminate defective oocytes. Dev. Cell 28:561-572.
Cushman, R. A., M. F. Allan, L. A. Kuehn, W. M. Snelling, A. S. Cupp, and H. C. Freetly. 2009. Evaluation of antral follicle count and ovarian morphology in crossbred beef cows: Investigation of influence of stage of the estrous cycle, age, and birth weight. J. Anim. Sci. 87:1971-1980.

Dewailly, D., C. Y. Andersen, A. Balen, F. Broekmans, N. Dilaver, R. Fanchin, G. Griesinger, T. W. Kelsey, A. La Marca, C. Lambalk, H. Mason, S. M. Nelson, J. A. Visser, W. H. Wallace, and R. A. Anderson. 2014. The physiology and clinical utility of antiMullerian hormone in women. Hum. Reprod. Update 20:370-385.

Edmonson, A. J., L. J. Lean, L. D. Weaver, T. Farver, and G. Webster. 1989. A body condition scoring chart for Holstein dairy cows. J. Dairy Sci. 72:68-78.

Gobikrushanth, M., P. A. Dutra, T. C. Bruinje, M. G. Colazo, S. T. Butler, and D. J. Ambrose. 2017. Repeatability of antral follicle counts and anti-Müllerian hormone and their associations determined at an unknown stage of follicular growth and an expected day of follicular wave emergence in dairy cows. Theriogenology 92:90-94.

Hansen, R. K., A. Mund, S. L. Poulsen, M. Sandoval, K. Klement, K. Tsouroula, M. A. X. Tollenaere, M. Raschle, R. Soria, S. Offermanns, T. Worzfeld, R. Grosse, D. T. Brandt, B. Rozell, M. Mann, F. Cole, E. Soutoglou, A. A. Goodarzi, J. A. Daniel, N. Mailand, and S. Bekker-Jensen. 2016. SCAI promotes DNA double-strand break repair in distinct chromosomal contexts. Nat. Cell Biol. 18:1357-1366.

Ireland, J. J., G. W. Smith, D. Scheetz, F. Jimenez-Krassel, J. K. Folger, J. L. H. Ireland, F. Mossa, P. Lonergan, and A. C. O. Evans. 2011. Does size matter in females? An overview of the impact of the high variation in the ovarian reserve on ovarian function and fertility, utility of anti-Mullerian hormone as a diagnostic marker for fertility and causes of variation in the ovarian reserve in cattle. Reprod. Fertil. Dev. 23:1-14.

Ireland, J. L. H., D. Sheetz, F. Jimenez-Krassel, A. P. N. Themmen, F. Ward, P. Lonergan, G. W. Smith, G. I. Perez, A. C. O. Evans, and J. J. Ireland. 2008. Antral follicle count reliably predicts number of morphologically healthy oocytes and follicles in ovaries of young adult cattle. Biol. Reprod. 79:1219-1225.

Jimenez-Krassel, F., J. K. Folger, J. L. H. Ireland, G. W. Smith, X. Hou, J. S. Davis, P. Lonergan, A. C. O. Evans, and J. J. Ireland. 2009. Evidence that high variation in ovarian reserves of healthy young adults has a negative impact on the corpus luteum and endometrium during reproductive cycles of single-ovulating species. Biol. Reprod. 80:1272-1281.

Jimenez-Krassel, F., D. Scheetz, L. Neuder, J. Ireland, J. Pursley, G. Smith, R. Tempelman, T. Ferris, W. Roudebush, and F. Mossa. 2015. Concentration of anti-Müllerian hormone in dairy heifers is positively associated with productive herd life. J. Dairy Sci. 98:3036-3045.

La Marca, A., and A. Volpe. 2006. Anti-Müllerian hormone (AMH) in female reproduction: Is measurement of circulating AMH a useful tool? Clin. Endocrinol. (Oxf.) 64:603-610.

Minozzi, G., E. L. Nicolazzi, A. Stella, S. Biffani, R. Negrini, B. Lazzari, P. Ajmone-Marsan, and J. L. Williams. 2013. Genome wide analysis of fertility and production traits in Italian Holstein cattle. PLoS One 8:e80219.

Monniaux, D., L. Drouilhet, C. Rico, A. Estienne, P. Jarrier, J. Touzé, J. Sapa, F. Phocas, J. Dupont, R. Dalbiès-Tran, and S. Fabre. 2012. Regulation of anti-Müllerian hormone production in domestic animals. Reprod. Fertil. Dev. 25:1-16.

Mossa, F., F. Carter, S. W. Walsh, D. A. Kenny, G. W. Smith, J. L. Ireland, T. B. Hildebrandt, P. Lonergan, J. J. Ireland, and A. C. O. Evans. 2013. Maternal undernutrition in cows impairs ovarian and cardiovascular systems in their offspring. Biol. Reprod. 88:92.

Mossa, F., S. W. Walsh, S. T. Butler, D. P. Berry, F. Carter, P. Lonergan, G. W. Smith, J. J. Ireland, and A. C. O. Evans. 2012. Low numbers of ovarian follicles $\geq 3 \mathrm{~mm}$ in diameter are associated with low fertility in dairy cows. J. Dairy Sci. 95:2355-2361.

Nawaz, M. Y., F. Jimenez-Krassel, J. P. Steibel, Y. Lu, A. Baktula, N. Vulkasinovic, S. K. DeNise, L. Neuder, J. L. H. Ireland, J. J. Ireland, and R. J. Tempelman. 2017. Genome wide association 
analysis and genomic heritability for AMH in Holstein dairy heifers (Abstract). Annual meeting of American Dairy Science Association, Pittsburgh, Pennsylvania. J. Dairy Sci. 100(Suppl. 2):132.

Ogoh, H., N. Tanuma, Y. Matsui, N. Hayakawa, A. Inagaki, M. Sumiyoshi, Y. Momoi, A. Kishimoto, M. Suzuki, N. Sasaki, T. Ohuchi, M. Nomura, Y. Teruya, K. Yasuda, T. Watanabe, and H. Shima. 2016. The protein phosphatase 6 catalytic subunit (Ppp6c) is indispensable for proper post-implantation embryogenesis. Mech. Dev. 139:1-9.

Ohbayashi, N., M. Shibayama, Y. Kurotaki, M. Imanishi, T. Fujimori, N. Itoh, and S. Takada. 2002. FGF18 is required for normal cell proliferation and differentiation during osteogenesis and chondrogenesis. Genes Dev. 16:870-879.

Ornitz, D. M., and N. Itoh. 2015. The Fibroblast Growth Factor signaling pathway. Wiley Interdiscip. Rev. Dev. Biol. 4:215-266.

Purcell, S., B. Neale, K. Todd-Brown, L. Thomas, M. A. Ferreira, D. Bender, J. Maller, P. Sklar, P. I. De Bakker, and M. J. Daly. 2007. PLINK: A tool set for whole-genome association and populationbased linkage analyses. Am. J. Hum. Genet. 81:559-575.

Ribeiro, E. S., R. S. Bisinotto, F. S. Lima, L. F. Greco, A. Morrison, A. Kumar, W. W. Thatcher, and J. E. P. Santos. 2014. Plasma anti-Müllerian hormone in adult dairy cows and associations with fertility. J. Dairy Sci. 97:6888-6900.

Rico, C., S. Fabre, C. Médigue, N. di Clemente, F. Clément, M. Bontoux, J. L. Touzé, M. Dupont, E. Briant, B. Rémy, J. F. Beckers, and D. Monniaux. 2009. Anti-Müllerian hormone is an endocrine marker of ovarian gonadotropin-responsive follicles and can help to predict superovulatory responses in the cow. Biol. Reprod. 80:50-59.

Sargolzaei, M., J. P. Chesnais, and F. S. Schenkel. 2014. A new approach for efficient genotype imputation using information from relatives. BMC Genomics 15:478.

Swets, J. A. 1988. Measuring the accuracy of diagnostic systems. Science 240:1285-1293.

Walsh, S. W., F. Mossa, S. T. Butler, D. P. Berry, D. Scheetz, F. Jimenez-Krassel, R. J. Tempelman, F. Carter, P. Lonergan, A. C. Evans, and J. J. Ireland. 2014. Heritability and impact of environmental effects during pregnancy on antral follicle count in cattle. J. Dairy Sci. 97:4503-4511.

Yang, J., B. Benyamin, B. P. McEvoy, S. Gordon, A. K. Henders, D. R. Nyholt, P. A. Madden, A. C. Heath, N. G. Martin, G. W. Montgomery, M. E. Goddard, and P. M. Visscher. 2010. Common SNPs explain a large proportion of the heritability for human height. Nat. Genet. 42:565-569.

Yang, J., S. H. Lee, M. E. Goddard, and P. M. Visscher. 2011. GCTA: A tool for genome-wide complex trait analysis. Am. J. Hum. Genet. $88: 76-82$

Yang, J., N. A. Zaitlen, M. E. Goddard, P. M. Visscher, and A. L. Price. 2014. Mixed model association methods: Advantages and pitfalls. Nat. Genet. 46:100-106. 